PRACE GEOGRAFICZNE

zeszyt 151, 2017, 135-152

doi: 10.4467/20833113PG.17.026.8038

Instytut Geografii i Gospodarki Przestrzennej UJ

Wydawnictwo Uniwersytetu Jagiellońskiego

\title{
O REPREZENTATYWNOŚCI DEUGOLETNICH, INTERDYSCYPLINARNYCH BADAŃ PASTERSTWA W CZARNOHORZE
}

\author{
Mateusz Troll
}

\section{On the representativeness of long-time, interdisciplinary research upon shepherding in the Chornohora}

\begin{abstract}
The paper discusses chosen results of the third part of long-time, interdisciplinary studies on Hutsul summer farming in the Chornohora mountains, published in a book titled Pasterstwo w Caarnohorze (the English title: Shepherding in the Chornohora). Janusz Gudowski (the book's editor) claims that the representativeness of the research carried out by his team in a small part of the Chornohora (Mt Kukul), is high, which is a matter of discussion here. The paper's author argues with the applied research approach, which does not take into consideration a possible variation of economic relations in different grazing seasons and its influence on summer farming change. Examples of changes investigated during this research, and caused by such a variation, are discussed in the paper as a separate category of interdisciplinary study results, which cannot be extrapolated outside the study area. Treating such results as representative could give a false view of summer farming changes. Above all, the study area used in this interdisciplinary research cannot be recognized in author's opinion as representative, when only relatively small secondary grasslands were investigated, resulting, among others, in overrepresentation of cattle farms as well as a lack of secondary succession symptoms. Among the most important features of the Chornohora summer livestock farming, not represented in the study area, and not described in this book, are sheep grazing in general (despite the English title of this book, only cattle grazing was investigated during this research) and communal grazing, both sheep and cattle. A different view on the role of long-time pasture ownership changes (1999-2014) and relations between the nature protection and summer farming in the Chornohora (two protected areas with different protection zones) is also presented in this paper.
\end{abstract}

Keywords: summer livestock farming, cattle and sheep grazing, mountain grasslands, representativeness, Chornohora; Hutsulshchyna 
Zarys treści: Artykuł ma związek z publikacją wyników trzeciego etapu interdyscyplinarnych badań pasterstwa huculskiego, prowadzonych przez zespół pod kierunkiem Janusza Gudowskiego w jednym z masywów górskich pasma Czarnohory na Ukrainie, w latach 1999, 2009 i 2014 (Pasterstwo w Caarnohorze pod redakcją J. Gudowskiego, wyd. I, Lublin 2016). Autor artykułu polemizuje z tezą J. Gudowskiego, mówiącą o dużej reprezentatywności wyników tych badań. Polemika dotyczy zastosowanego podejścia badawczego (połonina jako obiekt badań zjawiska cechującego się zmiennością sezonowych powiązań gospodarczych), wyboru obszaru badań (wyłącznie połoniny śródleśne masywu Kukula, otoczone borami iglastymi), roli ochrony przyrody w pastwiskowym użytkowaniu połonin (pominiętej w omawianych badaniach) oraz wyłaniającego się z pracy obrazu stosunków własnościowych na połoninach a także ich zmian w okresie 1999-2014. Zdaniem autora polemiki niereprezentatywność obszaru badań odzwierciedla się w wynikach badań, m.in. w postaci nadreprezentacji gospodarstw bydlęcych oraz braku oznak sukcesji wtórnej na użytkowanych pastwiskowo połoninach. W artykule zwrócono uwagę na najbardziej istotne, zdaniem autora, cechy charakterystyczne czarnohorskiego pasterstwa, pominięte w badaniach zespołu J. Gudowskiego - utrzymującą się dużą rolę pasterstwa owiec oraz powszechność w zakarpackiej części Czarnohory wypasu, zarówno owiec jak i bydła, organizowanego przez poszczególne gromady terytorialne. Poruszono również zagadnienie zmienności sezonowych powiązań w gospodarce huculskiej, powodującej, że niektóre z uzyskanych przez zespół J. Gudowskiego wyników badań przeobrażeń pasterstwa Czarnohory w okresie 1999-2014, nie mogą być ekstrapolowane poza obszar masywu Kukula a tym samym nie mogą być reprezentatywne dla Czarnohory lub całej Huculszczyzny.

Stowa kluczowe: pasterstwo wysokogórskie, wypas bydła i owiec, połoniny, reprezentatywność, Czarnohora, Huculszczyzna

\section{Wstęp}

Sezonowy wypas zwierząt na połoninach Huculszczyzny nie odgrywa współcześnie tak istotnej roli w gospodarce i kulturze tego regionu, jaką odgrywał w przeszłości, przede wszystkim z powodu spadku znaczenia samego chowu zwierząt we wsiach huculskich (Ławruk 2011a). Tam, gdzie wypas ten jest nadal prowadzony, stanowi on jednak ważny i w większości przypadków jedyny czynnik ograniczający zarastanie połonin, te mają bowiem przeważnie charakter wtórny bądź seminaturalny. Szczególną rolę w tym względzie odgrywa pasterstwo owiec (Mroczkowski 2004; Molik, Błasiak 2015), które - co warto tu podkreślić - stanowiło tradycyjne zajęcie Hucułów, w odróżnieniu od innych grup górali ruskich (por. Męciński 1938; Ławruk 2011b). Od tego, czy uda się ograniczyć procesy sukcesji wtórnej, przynajmniej na niektórych połoninach Huculszczyzny, zależy zarówno utrzymanie ich bioróżnorodności, jak i zachowanie pasterskiego krajobrazu kulturowego tego regionu (por. Metera i in. 2010; Sobala 2014). Rola pasterstwa huculskiego jest szczególnie dobrze widoczna w najwyższym paśmie górskim Huculszczyzny - Czarnohorze. Co najmniej do 
końca XIX w. cały obszar czarnohorskich połonin rozciągających się powyżej obniżonej przez pasterzy górnej granicy lasu, podzielony był na odrębne pastwiska (por. Troll 2013). Współcześnie natomiast, obok połonin pozostających jeszcze w użytkowaniu pastwiskowym, występują dawne pastwiska, zarastające wskutek wtórnej sukcesji lasu i zarośli subalpejskich (Caryk, Małynowskyj 1997; Kłymyszyn i in. 2007; Sitko, Troll 2008). W górach tych działa w dalszym ciągu wyjątkowo dużo sezonowych gospodarstw huculskich (ponad 40), reprezentujących różne kierunki chowu zwierząt oraz różne formy organizacyjne wypasu (Warchalska-Troll, Troll 2014). Różnorodności tej sprzyja zróżnicowanie warunków klimatyczno-roślinnych połonin (połoniny śródleśne, subalpejskie i alpejskie), występowanie różnych form ochrony przyrody, a także zróżnicowanie stosunków własnościowych na połoninach. Istotną cechą czarnohorskiego pasterstwa jest również jego duża zmienność w czasie. $Z$ jednej strony wiąże się ona ze zmiennością powiązań w huculskiej gospodarce pasterskiej, obowiązujących w poszczególnych sezonach pastwiskowych, z drugiej natomiast wynika ze zmian w polityce gospodarowania ziemią (Ławruk 2011a; Warchalska-Troll, Troll 2014), a także szybko postępującej w ostatnich latach budowy dróg prowadzących na połoniny, zwłaszcza w części zakarpackiej Czarnohory (C:etwertyna... 2016).

Odmienny obraz zróżnicowania pasterstwa Czarnohory wyłania się z długoletnich badań interdyscyplinarnych, których kolejne wyniki opublikowano w opracowaniu zbiorowym pt. Pasterstwo w Cæarnohoræe. Przyczynki do badań kultury huculskiej $\left(\right.$ Gudowski 2016) ${ }^{1}$. Badania te prowadzone były w sezonach pastwiskowych 1999 , 2009 i 2014 przez polsko-ukraiński zespół pod kierunkiem ekonomisty rolnego Janusza Gudowskiego, będącego także redaktorem tego opracowania, jak również redaktorem dwóch wcześniejszych publikacji z wynikami badań zespołu (Gudowski 2001b, 2011b)². W ramach tych długoletnich badań Janusz Gudowski oraz Jacek Hucuł-Stróżewski (zootechnik) zajmowali się gospodarką pasterską (Gudowski 2001a, 2011a; Hucuł-Stróżewski 2011; Gudowski, Hucuł-Stróżewski 2016), Włodzimierz Witkowski (architekt) - kulturą materialną, a ściślej budownictwem pasterskim (Witkowski 2001, 2011, 2016), natomiast Jurij Nesteruk (ukraiński geograf ekolog) szatą roślinną połonin (Nesteruk 2001, 2011, 2016). Wymieniam tu jedynie tych

\footnotetext{
${ }^{1}$ W 2017 r. ukazało się drugie wydanie tego opracowania (Gudowski J. (red.), 2017, Pasterstwo w Cæarnohorze. Przyczynki do badań kultury huculskiej, Libra PL, Rzeszów). W spisie literatury do tego wydania dodano pozycję, której jestem współautorem (Warchalska-Troll, Troll 2014), mimo że pozycja ta nie jest w tym opracowaniu nigdzie cytowana.

${ }^{2}$ Pierwsza praca tego zespołu, w której przedstawiono wyniki badań prowadzonych w 1999 r. (Gudowski 2001b), jest moim zdaniem jednym z najważniejszych opracowań o charakterze monograficznym, jakie na temat pasterstwa w Czarnohorze, a raczej szerzej - pasterstwa na Huculszczyźnie - dotychczas opublikowano.
} 
członków zespołu badawczego, których wyniki badań składają się na obraz pasterstwa Czarnohory, będący przedmiotem dyskusji w niniejszym artykule ${ }^{3}$.

Jeśli zespół mający w swoim gronie specjalistów w różnych dziedzinach, a zarazem niekwestionowanych znawców Czarnohory i Huculszczyzny, przedstawia wyniki swoich długoletnich badań pod tak obiecującym, monograficznym tytułem (tytuł okładkowy to Pasterstwo w C:arnohoræe), niejeden czytelnik, po lekturze tej publikacji, będzie skłonny uznać, że w Czarnohorze owiec się już nie wypasa, połoniny są prywatną własnością Hucułów, ich pastwiskowe użytkowanie sprawia, iż w ogóle nie zarastają, a ewentualne usytuowanie połoniny na obszarze chronionym nie ma dla jej użytkowania żadnego znaczenia. W zasadzie czytelnik może w taki właśnie sposób pomyśleć nie tylko o pasterstwie Czarnohory, ale i całej Huculszczyzny, skoro redaktor J. Gudowski zapewnia we wstępie: „Chociaż pod względem obszarowym badania dotyczą zaledwie wycinka Huculszczyzny, to jednak ich reprezentatywność jest znaczna" (2016: 7). Chyba należy rozumieć to tak, że na podstawie opracowania dotyczącego pasterstwa w najwyższym paśmie górskim Ukrainy - tytułowej Czarnohorze - czytelnicy mogą wyrobić sobie pogląd na temat pasterstwa w regionie Huculszczyzny. Ponieważ jednak w opracowaniu tym wszystkie informacje odnoszące się do pasterstwa Czarnohory dotyczą badanego przez zespół J. Gudowskiego wycinka tej grupy górskiej, tj. masywu Kukula (ryc. 1), jego reprezentatywność ma znaczenie kluczowe. Jakkolwiek ten niewielki wycinek Czarnohory, dzięki długoletnim, interdyscyplinarnym badaniom zespołu J. Gudowskiego jest chyba najlepiej poznanym, jeśli chodzi o współczesne pasterstwo huculskie i jego przeobrażenia, nie można się moim zdaniem zgodzić z cytowaną wyżej tezą o dużej reprezentatywności badań prowadzonych na tym obszarze ${ }^{4}$.

Głównym celem niniejszych rozważań jest wykazanie, że badania pasterstwa prowadzone w masywie Kukula nie mogą być traktowane jako reprezentatywne dla Czarnohory. Dotyczy to moim zdaniem nie tylko wyników badań prowadzonych w sezonie pastwiskowym 2014, ale również niektórych wyników badania przeobrażeń pasterstwa w piętnastoleciu 1999-2014. W rozważaniach na temat reprezentatywności wybranych połonin Kukula biorę pod uwagę zarówno warunki

\footnotetext{
${ }^{3}$ Poza wyżej wymienionymi w skład zespołu wchodzili również: A. Ruszczak (krajoznawca, z zawodu lekarz), M. Kropiwnicki (geograf), W. Żakowski (historyk-dokumentalista), K. Tur-Marciszuk (historyk sztuki) oraz F. Gudowski, W. Gudowski, N. Nesteruk i Sz. Marciszuk, a w przeszłości także M. Ząbek (antropolog kultury), H. Konarski (zootechnik, ekonomista i socjolog wsi) i A. Kosiek (zootechnik).

${ }^{4}$ Należy dodać, że jednemu z członków tego zespołu, W. Witkowskiemu, zawdzięczamy również kilkuletnią (2007, 2011 i 2013) serię obserwacji budownictwa pasterskiego na sąsiadujących z Czarnohorą Połoninach Hryniawskich (Górach Hryniawskich), których wyniki przedstawiono w tej samej publikacji (Witkowski 2016). Wyniki te mają tym większą wartość, że o współczesnym stanie pasterstwa na Połoninach Hryniawskich niewiele wiadomo (por. Ławruk 2011a, b). Dowodzą one jednak, że również w badanej przez W. Witkowskiego części Połonin Hryniawskich nie występują te cechy charakterystyczne pasterstwa huculskiego, na których brak w masywie Kukula, pragnę zwrócić uwagę.
} 
przyrodnicze oraz status ochronny połonin, jak i stosunki własnościowe. Od tych czynników zależy bowiem, przynajmniej w jakimś stopniu to, jacy konkretnie uczestnicy rynku będą się pojawiać w badanym wycinku przestrzeni w poszczególnych sezonach (organizator wypasu oraz zatrudniani przez niego pracownicy), a co za tym idzie, jakie zwierzęta będą trafiać na badane połoniny (np. kierunek chowu) oraz z których wsi zwierzęta te będą pochodzić (czarnohorskich, a może także spoza Czarnohory). Jeśli zróżnicowanie warunków przyrodniczych lub własnościowych w obszarze badań nie będzie reprezentatywne dla użytkowanych pastwiskowo połonin Czarnohory, niektórych cech charakterystycznych czarnohorskiego pasterstwa można w trakcie takich badań nie wychwycić. Przedmiotem polemiki jest również zastosowanie w badaniach przeobrażeń pasterstwa Czarnohory podejścia badawczego, w którym obiektem badań zjawiska cechującego się zmiennością sezonowych powiązań jest połonina.

\section{Obszar i obiekt długoletnich, interdyscyplinarnych badań pasterstwa Czarnohory}

Badany przez zespół J. Gudowskiego „wycinek Huculszczyzny” obejmuje wybrane połoniny masywu Kukula (1534 m n.p.m.), stanowiąc niewielki wycinek pasma Czarnohory (ryc. 1). W 2014 r. badania te prowadzono na siedmiu połoninach tego masywu ${ }^{5}$, w siedmiu działających tam wówczas gospodarstwach pasterskich - po jednym na każdej z wybranych połonin. Ponieważ autorzy nie podają, jak się ma liczba tych gospodarstw do ogółu czarnohorskich gospodarstw sezonowych, warto to uzupełnić - pod koniec pierwszej dekady XXI w. w Czarnohorze działało ponad 40 takich gospodarstw (ryc. 1; por. Warchalska-Troll, Troll 2014). Choć liczba ta może się nieznacznie zmieniać z roku na rok, jej znajomość pozwala zorientować się, jaką część zbiorowości czarnohorskich gospodarstw objęto badaniami. Relacja jedna połonina - jedno gospodarstwo, z którą zespół J. Gudowskiego miał do czynienia w masywie Kukula w 2014 r., nie zdarza się często, zwłaszcza w rejonach Czarnohory objętych wypasem owiec. W niektórych gospodarstwach Czarnohory użytkuje się więcej połonin niż jedną, jednocześnie na niektórych połoninach występują po dwa gospodarstwa - jedno bydlęce i jedno owczarskie (Troll, Sitko 2006).

Wybór określonej połoniny jako obiektu badań, zamiast np. gospodarstwa pasterskiego, sprawia, że badania koncentrują się w danym wycinku przestrzeni,

\footnotetext{
${ }^{5}$ Oprócz siedmiu połonin (gospodarstw) na Kukulu, zespół J. Gudowskiego w latach 1999 i 2009 prowadził również badania w gospodarstwach działających na innych połoninach Czarnohory a także pasma Świdowca, natomiast jeden z członków tego zespołu (W. Witkowski) dodatkowe obserwacje poczynił w innych latach w wybranych gospodarstwach Połonin Hryniawskich (por. przyp. 3).
} 
w którym zjawisko o charakterze sezonowym, jakim jest pasterstwo wysokogórskie, teoretycznie może (ale nie musi) w określonym sezonie zaistnieć. Rozróżnienie to ma znaczenie drugorzędne, kiedy wnioskowanie na podstawie uzyskanych wyników badań dotyczy wyłącznie badanego wycinka przestrzeni. Warunek ten spełnia większość dotychczasowych badań empirycznych dotyczących pasterstwa w Czarnohorze (np. Kubijowicz 1926; Kubijovyč 1935, 1937; Woźnowski 1930; Troll, Sitko 2006; Sitko, Troll 2008; Ławruk 2011a; Troll 2012, 2013; Warchalska-Troll, Troll 2014). Ponieważ jednak w badaniach zespołu J. Gudowskiego (2001b, 2011b, 2016) badany wycinek przestrzeni traktowany jest jako reprezentatywny dla większego obszaru (Czarnohora, Huculszczyzna), wybór połoniny jako obiektu badań niesie za sobą określone konsekwencje, omówione poniżej.

\section{Reprezentatywność wybranych połonin Kukula jako obszaru badań nad gospodarką i kulturą pasterską oraz szatą roślinną połonin Czarnohory}

W rozważaniach nad reprezentatywnością połonin Kukula można wyodrębnić dwie grupy zagadnień. Pierwsza dotyczy roli zmienności sezonowych powiązań w gospodarce huculskiej na tym obszarze (podrozdz. 3.1), druga natomiast roli określonych cech tego obszaru, zarówno jeśli chodzi o warunki przyrodnicze i status ochronny połonin (podrozdz. 3.2), jak i stosunki własnościowe panujące na połoninach oraz związane z nimi formy organizacyjne sezonowego wypasu zwierząt (podrozdz. 3.3).

\section{Zmienność sezonowych powiązań w gospodarce pasterskiej a badania przeobrażeń tej gospodarki}

Jeśli badania przeobrażeń w gospodarce pasterskiej prowadzone są na tych samych połoninach w różnych sezonach pastwiskowych, to wyniki takich badań mogą być obarczone wpływem zmienności sezonowych powiązań występujących w tej gospodarce. Powiązań sezonowych, a więc będących wynikiem decyzji podejmowanych w związku z organizacją wypasu w poszczególnych sezonach pastwiskowych. Mimo że wiele z powiązań nie musi ulegać z sezonu na sezon żadnym zmianom, w przypadku badań prowadzonych przez dłuższy czas - a do takich należy zaliczyć badania zespołu J. Gudowskiego - w pasterstwie czarnohorskim zmian tego rodzaju nie można wykluczać. Chodzi tu w szczególności o zmiany w dzierżawie pastwisk, które nie zachodzą prawdopodobnie tak często, jak zmiany innych powiązań, jednak pociągają za sobą najdalej idące konsekwencje w przypadku badań prowadzonych na określonych połoninach. Wraz ze zmianą dzierżawcy danej połoniny, na połoninie tej zmienić się może kierunek chowu zwierząt preferowany przez danego organizatora 
wypasu (dzierżawcę), bądź też zmienić się mogą dostawcy zwierząt powierzanych na wypas, z którymi dany organizator wypasu współpracuje. Mogą również mieć miejsce zmiany w zatrudnieniu najemnych pracowników (pasterzy, dojarzy), wreszcie nie można wykluczyć zmian w budownictwie na użytkowanych połoninach. Nawet jeśli na danej połoninie nie zmienia się przez dłuższy czas sam organizator wypasu (w Czarnohorze jest to najczęściej dzierżawca, rzadziej właściciel), nie można wykluczyć zmian dostawców zwierząt, wynikających m.in. z konkurencji między różnymi organizatorami wypasu. Zmienność tego rodzaju powiązań powinno się rozpatrywać na tle zmian w stosunkach własnościowych oraz w dzierżawie połonin, tymczasem temu akurat zagadnieniu w publikacji Pasterstwo w C:arnohoræe poświęcono jedno zdanie, wymagające osobnego komentarza (rozdz. 3.3).

Jak dużą rolę odgrywa tego rodzaju zmienność we współczesnej gospodarce pasterskiej Czarnohory, trudno ocenić, ponieważ nie poświęcono jej, jak dotąd, osobnych badań. Przypuszczam, że nie jest ona współcześnie tak duża, jak np. w okresie międzywojennym, kiedy wiązała się m.in. z oddawaniem wielu połonin w dzierżawy w drodze licytacji (Kubijowicz 1926; Markowski i in. 1928). Na pewno jednak rola ta nie jest tak mała, aby była zaniedbywalna w badaniach przeobrażeń pasterstwa. Nie ulega wątpliwości, że z tego rodzaju zmiennością zespół badawczy miał do czynienia w przypadku co najmniej trzech z siedmiu badanych połonin. Na dwóch połoninach (Kiernyczkie i Zakukul) stwierdzano w pojedynczych sezonach gospodarstwa owczarskie zamiast bydlęcych (Gudowski, Hucuł-Stróżewski 2016: 23). Obydwa te przypadki mówią coś więcej o samej zmienności powiązań. Na połoninie Kiernyczkie w 1999 r. owce przebywały jedynie w pierwszej części sezonu, następnie zaś zostały zabrane na inną z czarnohorskich połonin (która to połonina nie była przez zespół badana; Gudowski 2001a). Zmiana ta miała miejsce w trakcie trwania sezonu, co jest cechą szczególną gospodarstw pasterskich określanych w dawnej literaturze jako staje podwójne (współcześnie podobne gospodarstwa stwierdzono również w innych rejonach Czarnohory; Troll, Sitko 2006; Troll 2010). Z kolei na połoninie Zakukul w 2009 r. owce znalazły się tylko dlatego, że organizator wypasu został zmuszony do zmiany połoniny z powodu zagrożenia ze strony wilków, występującego na innej z czarnohorskich połonin (Gudowski 2011a). Zmiana została więc w tym przypadku wymuszona przez zdarzenie losowe. Na trzeciej z połonin, na których zespół miał do czynienia ze zmiennością powiązań (połonina Kukul), występowała zmienna liczba gospodarstw bydlęcych (Gudowski 2011a: 28). O ile dwie pierwsze połoniny (Kiernyczkie i Zakukul) zostały ostatecznie wyłączone z wnioskowania o zmianach w pogłowiu zwierząt w okresie 1999-2014, o tyle w przypadku trzeciej (Kukul), autorzy tego nie zrobili, porównując pogłowie zwierząt i zatrudnienie w dwóch gospodarstwach działających na tej połoninie w 1999 r. z podobnymi cechami tylko jednego 
gospodarstwa, jakie tam działało w latach późniejszych ${ }^{6}$. Niestety nie są to najprawdopodobniej wszystkie przypadki zmienności powiązań, mogły mieć bowiem również miejsce inne zmiany dotyczące organizatorów wypasu oraz dostawców zwierząt powierzanych na wypas. Wzmianka o tym, że właściciel (dzierżawca?) połoniny Zakukul zmienia zarówno organizatorów wypasu, jak i całe wsie, z którymi współpracuje w zakresie przyjmowania zwierząt na wypas, potwierdza tylko, że problem ten występował. Niestety wzmiankę tę można znaleźć tylko we wcześniejszej publikacji (Gudowski 2011a: 28). Brak konkretnych danych na temat zmian organizatorów wypasu oraz wsi, z których pochodziły zwierzęta w każdym z badanych sezonów, z jednej strony utrudnia stwierdzenie skali zmienności powiązań dotyczących badanych połonin, z drugiej zaś potwierdza, że zespół J. Gudowskiego koncentrował się na badaniach gospodarki pasterskiej na wybranych połoninach, a nie na badaniach zjawiska pasterstwa czarnohorskiego czy też szerzej - huculskiego.

Można się tu posłużyć dwoma przykładami wyników badania przeobrażeń pasterstwa, które odnoszą się do zmian zachodzących na połoninach Kukula, a których ewentualna ekstrapolacja na obszar Czarnohory może prowadzić do fałszywych wniosków. Pierwszy dotyczy stwierdzonego w 2014 r. braku wypasu owiec na połoninach Kukula (Gudowski, Hucuł-Stróżewski 2016). To, że owce po raz ostatni zespół badawczy stwierdził na badanych połoninach w 2009 r., nie oznacza, że w Czarnohorze przestał być obecny ten najbardziej tradycyjny kierunek chowu zwierząt na Huculszczyźnie. Szacowana w sezonach 2009-2013 liczba owiec pasących się na połoninach Czarnohory, użytkowanych przez kilkanaście gospodarstw owczarskich, sięgała 5500 sztuk/sezon (ryc. 1; fot. 1 i 2; Warchalska-Troll, Troll 2014). Niestety autorzy nie komentują braku wypasu owiec na obszarze badań w 2014 r. ${ }^{7}$, koncentrując się na analizie zmian w strukturze stad bydła (krowy dojne i bydło opasowe). Drugim przykładem są wyniki badania zmian w zatrudnieniu przy sezonowym wypasie zwierząt. J. Gudowski i J. Hucuł-Stróżewski (2016) stwierdzili spadek całkowitej liczby osób zatrudnionych, w stosunku do pogłowia zwierząt, pomiędzy 1999 i 2014 r. Jeśli jednak na danej połoninie zmienia się organizator wypasu, to wraz z nim mogą się zmieniać najemni pracownicy, z którym on na stałe współpracuje. Nie wiemy, z iloma tego rodzaju przypadkami zespół miał do czynienia w badanym piętnastoleciu.

Stwierdzona w przypadku połonin Kukula zmienność sezonowych powiązań w gospodarce pasterskiej sprawia, że uzyskane wyniki badań przeobrażeń zacho-

\footnotetext{
${ }^{6}$ Drugie z tych gospodarstw przeniosło się na inną z czarnohorskich połonin, o czym J. Gudowski wspomina, ale jedynie w starszej publikacji (2011a: 28).

${ }^{7}$ Brak pasterstwa owiec na połoninach Kukula w sezonie pastwiskowym 2014 zmniejsza niewątpliwie reprezentatywność niektórych wyników badań życia codziennego na połoninach Kukula, prezentowanych w omawianym opracowaniu zbiorowym (Marciszuk 2016; Tur-Marciszuk 2016), badaniami tymi objęto bowiem jedynie pasterzy bydła.
} 
dzących w tamtejszej gospodarce w ciągu 15 lat, nie powinny być moim zdaniem ekstrapolowane na większy obszar. Jakkolwiek sami autorzy wyników tych nie ekstrapolują, to prezentują je jednak w publikacji poświęconej pasterstwu w Czarnohorze, określając jednocześnie obszar, na którym zostały one uzyskane, jako reprezentatywny. Nawet jeśli wyniki te reprezentują cechy charakterystyczne jakiejś większej zbiorowości połonin, to tego rodzaju reprezentatywność należałoby moim zdaniem określić jako pozorną.

Można przypuszczać, że akurat pod względem omawianej tu zmienności powiązań, wybrane przez zespół J. Gudowskiego połoniny są w jakimś stopniu reprezentatywne dla Czarnohory. Przypuszczenie takie wydaje się uzasadnione, są bowiem wśród tych połonin zarówno takie, których zmienność ta dotyczyła, jak i takie, na których tego rodzaju zmiany nie zachodziły. Jak już wspomniałem, autorzy nie podają pełnych danych, które pozwoliłyby to ocenić. Można jedynie wyrazić żal, że zespół zainteresowany właśnie przeobrażeniami pasterstwa, pominął ten aspekt zmian w swoich badaniach.

\section{Reprezentatywność zróżnicowania warunków przyrodniczych oraz statusu ochronnego połonin użytkowanych jako sezonowe pastwiska}

Wszystkie badane przez zespół J.Gudowskiego połoniny masywu Kukula należą do najniżej położonych pastwisk górskich Czarnohory (poniżej 1500 m n.p.m.), znajdujących się w obrębie piętra leśnego, a więc mających charakter wtórny. Tego typu pastwiska występują również w innych rejonach Czarnohory (np. w sąsiednim masywie Kostryczy), jednak wiele czarnohorskich gospodarstw pasterskich użytkuje również rozległe pastwiska subalpejskie (seminaturalne), a co najmniej kilka gospodarstw także pastwiska alpejskie (Warchalska-Troll, Troll 2014; fot. 1). Odosobnienie masywu Kukula sprawia, że takich subalpejsko-alpejskich pastwisk nie ma także w jego bezpośrednim sąsiedztwie. Obydwa te czynniki - niskie położenie, a tym samym śródleśny charakter połonin Kukula, oraz odosobnienie masywu w połączeniu z niewielkimi rozmiarami tych połonin (każda ma po kilkadziesiąt hektarów) - mogą tłumaczyć tak wyraźną nadreprezentację gospodarstw bydlęcych na tych połoninach. Wypas owiec w Czarnohorze odbywa się często na wyżej położonych połoninach subalpejskich, a nawet alpejskich (mimo że szałasy znajdują się na ogół w pobliżu obniżonej górnej granicy lasu). Pastwiska takie są z reguły trudniej dostępne dla bydła (Harasymczuk, Tabor 1937; por. Kuźnicka 2008) oraz bardziej rozległe - a więc odpowiednie dla wypasu owiec, zgodnie z huculskim powiedzeniem „owca lubi chodzić” (por. Warchalska-Troll, Troll 2014), jednocześnie zaś cechują się one gorszą jakością runi pastwiskowej. To, że w badaniach prowadzonych na Kukulu w 2014 r. nie stwierdzono żadnego 
gospodarstwa owczarskiego, nie świadczy o jakimś pechu zespołu badawczego, już raczej pojawienie się takiego gospodarstwa w 2009 r. można uznać za zbieg okoliczności - szczęśliwy dla badaczy, choć, jak już wspomniałem, jednocześnie pechowy dla organizatora wypasu owiec.

Rozważając reprezentatywność warunków przyrodniczych połonin Kukula należy zwrócić również uwagę na zróżnicowanie składu gatunkowego lasów występujących $\mathrm{w}$ ich otoczeniu. W przypadku wszystkich tych połonin przedstawia się ono bardzo podobnie - w ich otoczeniu dominują bory świerkowe (Nesteruk 2016), tymczasem zmiany w szacie roślinnej połonin sąsiadujących z lasami bukowymi przebiegają inaczej niż w sąsiedztwie świerczyn, na co zwracano już uwagę wielokrotnie (np. Środoń 1948; Kucharzyk 2006; por. Sitko, Troll 2008).

Pod względem statusu ochronnego, dwie z badanych połonin Kukula (Łabieska i Zakukul) znajdują się na terenie Karpackiego Parku Narodowego (KPN) - obszaru chronionego znajdującego się w części pasma Czarnohory należącej do obwodu iwano-frankiwskiego (ryc. 1; por. Krukar, Troll 2013) - w strefie ochrony określanej jako strefa gospodarcza. Niestety sami autorzy nie wspominają o ochronie tych dwóch z siedmiu badanych połonin, co sugeruje brak jakiegokolwiek wpływu usytuowania niektórych pastwisk na obszarach chronionych na współczesne przeobrażenia pasterstwa ${ }^{8}$. Wśród wybranych połonin nie ma niestety żadnej chronionej w Karpackim Rezerwacie Biosfery (KRB), znajdującym się w części pasma należącej do obwodu zakarpackiego (ryc. 1). Tymczasem na obszarze KRB znajduje się łącznie znacznie więcej połonin objętych sezonowym wypasem zwierząt, niż na terenie KPN (ryc. 1; por. Warchalska-Troll, Troll 2014, mapa). Polityka w zakresie pastwiskowego użytkowania połonin w tych obszarach chronionych zależy zarówno od regulacji prawnych obowiązujących dla danej formy ochrony (odmienne strefowanie obydwóch obszarów chronionych), jak i od polityki danego obwodu administracyjnego w zakresie oddawania gruntów w dzierżawy (Warchalska-Troll, Troll 2014). To, że ochrona połonin użytkowanych pastwiskowo może być iluzoryczna, nie zmienia faktu, że organizator wypasu każdorazowo musi się starać o zezwolenie na wypas oraz na ewentualne przebywanie zwierząt w sąsiadujących z połoninami lasach, nie może również podejmować zabiegów mających na celu powstrzymanie sukcesji wtórnej na takim pastwisku bez uzyskania odpowiedniej zgody.

Ponieważ w ramach interdyscyplinarnych badań zajmowano się również zmianami w szacie roślinnej połonin, nasuwa się pytanie czy zmiany stwierdzone na tak wybranych połoninach mogą reprezentować przeobrażenia szaty roślinnej zachodzące na połoninach Czarnohory. Niewątpliwie nie mogą, ponieważ zespół badał w zasadzie

${ }^{8}$ Jedyna informacja dotycząca statusu ochronnego badanych połonin, podana we wcześniejszej pracy (Gudowski 2011a), dotyczy innej z badanych wówczas połonin (Wesnarka w masywie Kostryczy), którą autorzy omyłkowo uznali za znajdującą się w parku narodowym (por. ryc. 1; Krukar, Troll 2013). 
jedną kategorię połonin, stanowiących stosunkowo niewielkie pastwiska śródleśne, na których systematycznie pasie się bydło. Dlatego nie dziwi wniosek J.Nesteruka, że „groźba zarastania połonin jest niewielka” (Nesteruk 2016: 19). Ponieważ autor nie opatrzył tego wniosku żadnym komentarzem, nie wiadomo w jakim stopniu dotyczy on innych użytkowanych pastwiskowo połonin Czarnohory. O tym, że czarnohorskie połoniny pozostające w użytkowaniu pastwiskowym sukcesywnie zarastają, świadczą m.in. zmiany górnej granicy lasu stwierdzone w otoczeniu największego kompleksu połonin Czarnohory Zachodniej (Sitko, Troll 2008). Warto też podkreślić, że zarastanie na przestrzeni XX w. dawnych pastwisk znajdujących się powyżej antropogenicznie obniżonej górnej granicy lasu jest zjawiskiem powszechnym w całych Karpatach (Shandra i in. 2013).

\section{Reprezentatywność zróżnicowania stosunków własnościowych na połoninach oraz form organizacyjnych sezonowego wypasu zwierząt}

Obok warunków przyrodniczych i statusu ochronnego, kolejnym kryterium wyboru połonin powinien być ich status własnościowy i związana z nim podstawa prawna do ich użytkowania. W omawianej pracy temu ważnemu zagadnieniu poświęcono niestety tylko jedno zdanie, mówiące, że udojem zwierząt w badanych gospodarstwach trudnią się wyłącznie właściciele połonin, z wyjątkiem gospodarstwa na połoninie Zakukul (Gudowski, Hucuł-Stróżewski 2016: 25). Gdyby istotnie wszystkie pozostałe z badanych połonin (poza połoniną Zakukul) była własnością prywatną, pozostawałoby to w sprzeczności z oficjalnymi danymi katastralnymi Der ̈̈geokadastru Ukrainy (Publiczna ... 2016) oraz innymi ogólnodostępnymi źródłami informacji na temat stosunków własnościowych na połoninach Czarnohory (Petriw 2008; Ławruk 2011a). Otóż większość gruntów czarnohorskich połonin pozostaje własnością państwa od czasu rozwiązania dawnych gospodarstw kolektywnych (Ławruk 2011a; por. Publiczna... 2016). Sprzedaż prywatnym właścicielom niewielkich działek wyodrębnionych na niektórych z tych połonin, była swego czasu głośnym wydarzeniem (por. Petriw 2008; Ławruk 2011a), jednak zgodnie z danymi Der:̈geokadastru w obrębie badanych przez zespół J. Gudowskiego połonin Kukula, w ręce prywatnych właścicieli trafiło jedynie kilka dwuhektarowych działek na połoninie Hryhoriwka - nawet w tym przypadku łączna powierzchnia gruntów prywatnych stanowi niedużą część powierzchni całej połoniny (por. Publiczna... 2016). Nasuwa się więc pytanie, na jakich zasadach gospodarujący na połoninach Kukula pasterze użytkują państwowe połoniny (lub przynajmniej części połonin, jak w przypadku Hryhoriwki)? Według urzędowych danych, jakimi dysponuję, w zasadzie wszystkie połoniny zakarpackie w Czarnohorze, poza Kukulem, były co najmniej do 2011 r. użytkowane na podstawie sezonowych zezwoleń (Perelik... 2011). Z kolei 
w części Czarnohory znajdującej się w obwodzie iwano-frankiwskim, większość połonin państwowych znajdujących się poza strefą ochrony ścisłej KPN, zostało oddanych w dzierżawy długoterminowe, na maksymalny przewidziany przepisami Kodeksu ziemskiego Ukrainy okres 49 lat (Na Werchowynszczyni... 2011; Informacija ... 2015; por. też Troll 2012, 2013). Nasuwa się więc pytanie, kogo mają na myśli autorzy, pisząc o właścicielach połonin? Być może tych, którzy w wywiadach sami się tak określają. W praktyce może to oznaczać, przynajmniej w niektórych przypadkach, dzierżawców państwowych połonin, a w innych - prywatnych właścicieli niewielkich działek znajdujących się w obrębie tych połonin.

Należy tu podkreślić, że wśród badanych połonin Kukula nie ma ani jednego przykładu połoniny państwowej użytkowanej na podstawie sezonowego zezwolenia wydawanego dla określonej gromady (na Ukrainie określanej mianem gromady terytorialnej). Takie zezwolenia na wypas, wydawane przez rejonową administrację państwową, obowiązują na większości czarnohorskich połonin należących do obwodu zakarpackiego, zarówno znajdujących się na terenie KRB (w strefie, w której dopuszcza się sezonowy wypas zwierząt zwanej strefą krajobrazów antropogenicznych), jak i poza nim. O tej całkowicie odmiennej formie organizacyjnej wypasu zespół w ogóle nie wspomina, mimo że jej występowanie w Czarnohorze było już w literaturze sygnalizowane (np. Ławruk 2011a; Warchalska-Troll, Troll 2014).

Gospodarstwa prowadzone przez przedstawicieli gromad terytorialnych (fot. 2 i 3 ) można określić mianem komunalnych, choć posiadają one również pewne cechy gospodarstw wielorodzinnych. Do gospodarstw owczarskich działających na podstawie zezwoleń wydawanych poszczególnym gromadom, zalicza się ponad dziesięć (tj. ok. 1/4 wszystkich zinwentaryzowanych pod koniec pierwszej dekady XXI w. gospodarstw w Czarnohorze; por. Warchalska-Troll, Troll 2014). Połowa z tych gospodarstw należy do najbardziej prymitywnych ${ }^{9}$ spośród wszystkich gospodarstw pasterskich Czarnohory (ryc. 1; fot. 2). Są to gospodarstwa, w których pasterze gospodarują na połoninie w prowizorycznych szałasach (schrony pozbawione osłony od frontu, przypominające tzw. zastajki - por. Witkowski 2001; Troll 2010), ukrytych na ogół z dala od turystycznych ścieżek. Szałasy w tych gospodarstwach są tak niewielkie, że brak w nich miejsca na magazynowanie zarówno produktów gospodarki pasterskiej (w gospodarstwach tych wypasane są przede wszystkim owce dojne), jak i żywności dla personelu. $Z$ tego powodu zaopatrzenie dla pasterzy dostarczane jest rotacyjnie przez właścicieli zwierząt, udających się w tym celu na połoninę oraz odbierających jednocześnie przypadającą im ilość sera (Warchalska-Troll, Troll 2014). Owi właściciele zwierząt nie należą do personelu danego gospodarstwa, mają jednak swoje ściśle określone obowiązki i bez ich pracy takie gospodarstwo nie mogłoby funkcjonować. Ważną cechą niektórych gospodarstw bydlęcych działających w oparciu o analogiczne

\footnotetext{
${ }^{9}$ Określenie to w odniesieniu do gospodarstw nie ma tu mieć zabarwienia pejoratywnego.
} 


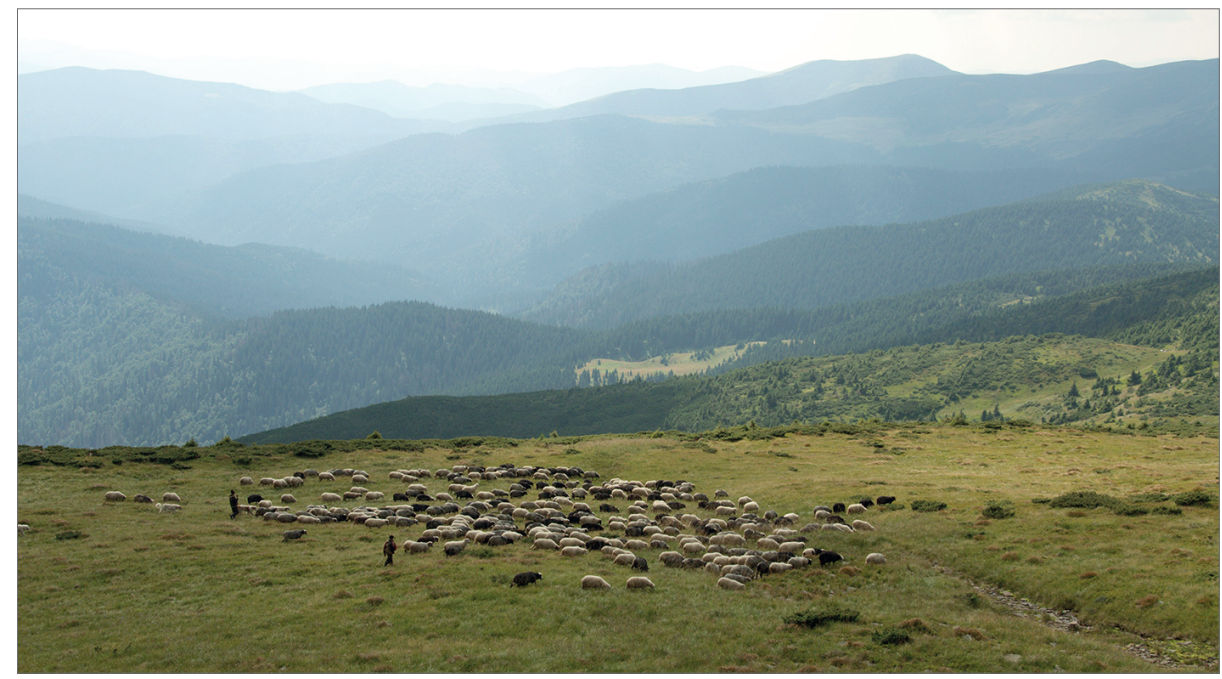

Fot. 1. Wypas owiec na jednej z subalpejskich połonin Czarnohory w sezonie 2009 (strefa buforowa KRB) (fot. M. Troll)

Photo 1. Sheep grazing on a subalpine pasture in the Chornohora in 2009 (buffer zone, CBR) (photo by M. Troll)

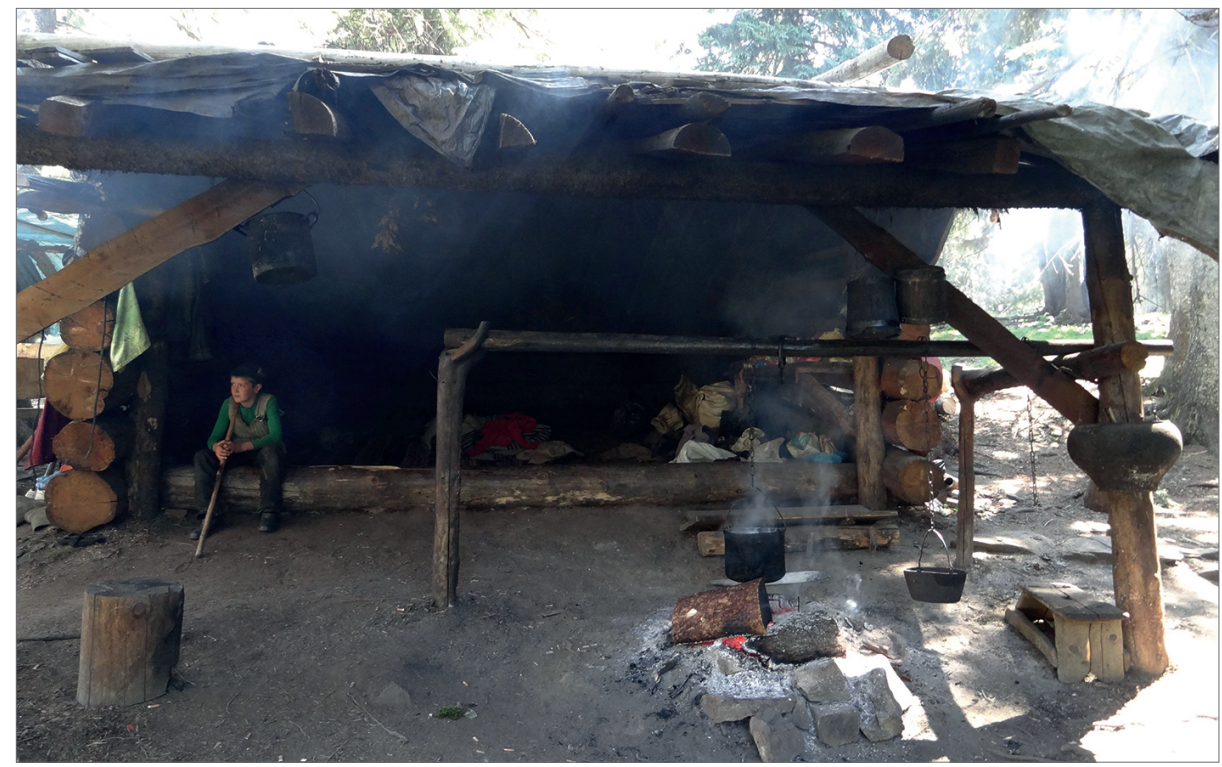

Fot. 2. Jedno z kilku prymitywnych gospodarstw owczych Czarnohory, prowadzone przez pasterzy z gromady Bogdan. Widoczny jedyny szałas mieszkalny pasterzy i miejsce wyrobu sera, stan w sezonie 2013 (strefa krajobrazów antropogenicznych KRB) (fot. A. Warchalska-Troll) Photo 2. One of the few primitive sheep farms in the Chornohora, used by the inhabitants of Bogdan community. View of the main building taken in 2013 - simple shelter for shepherds and place for the cheese production (zone of traditional management, CBR) (photo by A. Warchalska-Troll) 


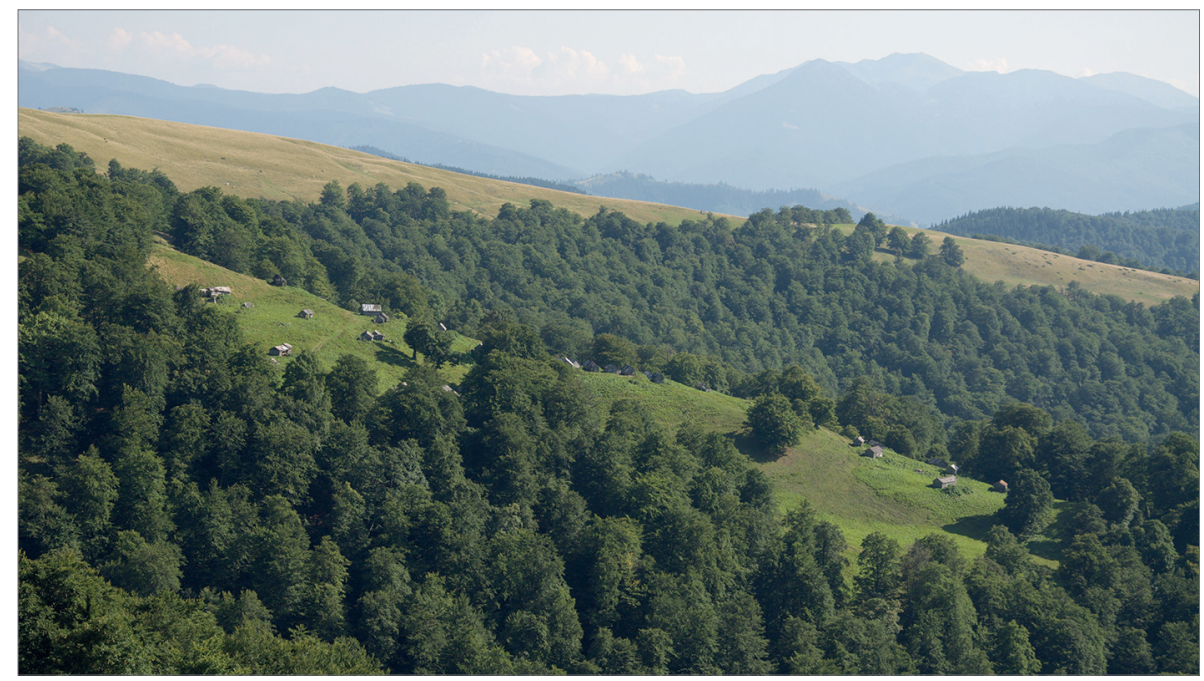

Fot. 3. Jedno z komunalnych gospodarstw bydlęcych Czarnohory, stan w sezonie 2010. Widoczne liczne obory należące do poszczególnych rodzin gromady Kwasy (fot. M. Troll) Photo 3. One of the communal cattle farms in the Chornohora, in 2010. View of numerous small barns built by families from the Kwasy community (photo by M. Troll)

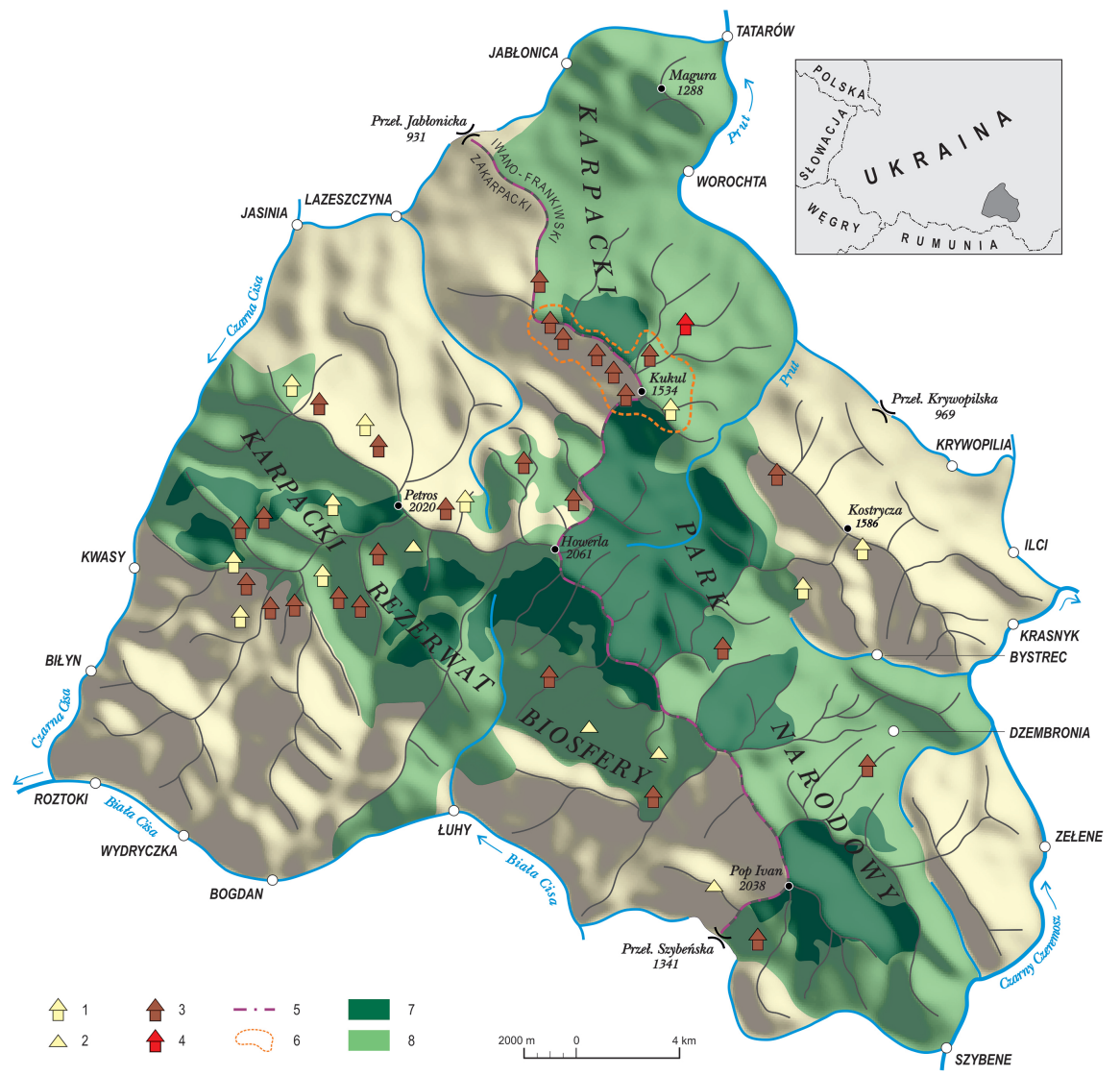


zezwolenia, upodabniającą je do gospodarstw wielorodzinnych, jest pochodzenie budynków inwentarskich. Poszczególne rodziny z danej gromady budują prowizoryczne obory dla własnych zwierząt powierzanych na wypas (Warchalska-Troll, Troll 2014). Skutkuje to na ogół chaotyczną zabudową, składającą się z dziesiątków niewielkich budynków inwentarskich (fot. 3), których rekordowa liczba w jednym z takich czarnohorskich gospodarstw przekracza 90 (Troll, Sitko 2006).

Specyficzny podział obowiązków właścicieli zwierząt (ich rodzin) oraz odmienne cechy zabudowy szałaśniczej (brak chatczyny, stai, a nawet kołyby ${ }^{10} \mathrm{w}$ gospodarstwach owczarskich oraz zgrupowania liczące po kilkadziesiąt niewielkich budowli inwentarskich w gospodarstwach bydlęcych), różnią te gospodarstwa od gospodarstw na Kukulu. Warto zauważyć, że połoniny użytkowane z roku na rok przez te same gromady mogą być eksploatowane inaczej niż połoniny podnajmowane przez indywidualnych gospodarzy od posiadaczy dzierżaw długoterminowych, zwłaszcza od tych, którzy dzierżawy takie uzyskali nie z myślą o rozwijaniu gospodarki pasterskiej, tylko np. o budowie hoteli lub wyciągów narciarskich (brak tego rodzaju inwestycji w Czarnohorze spowodowany jest prawdopodobnie głównie ograniczoną dostępnością komunikacyjną).

Nie mniej ważnym zagadnieniem, obok stosunków własnościowych panujących na połoninach w ostatnim badanym przez zespół J. Gudowskiego sezonie pastwisko-

$\overline{{ }^{10} \text { Budowle połonińskie szczegółowo opisywane m.in. przez W. Witkowskiego }(2001,2011,2016) .}$

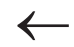

Ryc. 1. Gospodarstwa pasterskie Czarnohory na tle stref ochronnych Karpackiego Parku Narodowego i Karpackiego Rezerwatu Biosfery (stan w sezonie 2009).

Fig. 1. Summer livestock farms in the Chornohora operating at the end of the first decade of the 21st century versus protection zones of the Carpathian National Nature Park and the Carpathian Biosphere Reserve

Objaśnienia: 1 - gospodarstwa owcze; 2 - prymitywne gospodarstwa owcze wyróżniające się prowizoryczną zabudową szałaśniczą; 3 - gospodarstwa bydlęce; 4 - pasterskie gospodarstwo agroturystyczne; 5 - granica administracyjna pomiędzy obwodami iwano-frankiwskim i zakarpackim; 6 - gospodarstwa badane w latach 1999-2014 przez interdyscyplinarny zespół J.Gudowskiego (2011a, 2016); 7 - strefa ochrony ścisłej (KPN)/strefa centralna (KRB); 8 - pozostałe strefy ochronne (KPN, KRB).

Explanations: 1 - sheep farm; 2 - primitive sheep farm; 3 - cattle farm; 4 - agrotourism livestock farm; 5 - administrative boundary between the Ivano-Frankivsk Oblast and the Zakarpattia Oblast; 6 - farms investigated in 1999, 2009 and 2014 by the interdisciplinary team led by J.Gudowski (2011a, 2016); 7 - strictly protected zone (CNNP)/core zone (CBR); 8 - other protected zones (CNNP, CBR).

Źródto: opracowanie własne na podstawie: Warchalska-Troll, Troll 2014.

Source: map by M. Troll, based on Warchalska-Troll, Troll 2014. 
wym (2014), są tamtejsze zmiany własności ziemskiej w okresie 1999-2014. Niestety zagadnieniu temu ani w omawianej publikacji, ani we wcześniejszej pracy (Gudowski 2011b) nie poświęcono żadnej uwagi. Tymczasem wydaje się, że interpretacja przynajmniej niektórych, stwierdzonych w badanym piętnastoleciu przeobrażeń w gospodarce pasterskiej i kulturze materialnej gospodarstw, powinna uwzględniać moment, w którym pasterze określani przez J. Gudowskiego i J. Hucuła-Stróżewskiego mianem właścicieli, nabyli prawa własności do gruntów na połoninach Kukula (lub też kiedy stali się długoterminowymi dzierżawcami). Stosunkom własnościowym J. Gudowski poświęcił cały podrozdział w pracy, w której przedstawione zostały wyniki badań z 1999 r. (Gudowski 2001a), było to jednak na długo przed istotnymi zmianami, sygnalizowanymi powyżej. Można odnieść wrażenie, że na badanych połoninach Kukula w ciągu piętnastu lat nie zachodziły żadne zmiany stosunków własnościowych, niestety oznaczałoby to, że połoniny te również pod tym względem nie mogłyby być uznane za reprezentatywne dla Czarnohory. Niewątpliwie w tak długim okresie (15 lat), zmiany takie następowały, przynajmniej na niektórych połoninach Kukula, nasuwa się więc pytanie, czy zespół to zagadnienie starał się zgłębić - nie tylko na podstawie wywiadów na połoninach, ale również w urzędach administracji lokalnej?

\section{Wnioski}

Można wyrazić przypuszczenie, że dzięki badaniom zespołu J.Gudowskiego masyw Kukula reprezentuje wycinek Czarnohory, a zarazem Huculszczyzny, wyróżniający się wyjątkowo długą serią czasową wielotematycznych danych empirycznych na temat gospodarki i kultury pasterskiej oraz szaty roślinnej użytkowanych połonin. Nie można jednak zgodzić się z tezą J.Gudowskiego o dużej reprezentatywności wyników tych badań. Nie dostarczają one bowiem wiedzy o pewnych cechach charakterystycznych czarnohorskiej gospodarki pasterskiej oraz zachodzących w niej przeobrażeń, a także niektórych cechach charakterystycznych czarnohorskiego budownictwa pasterskiego, czy wreszcie cechach charakterystycznych zmian zachodzących w szacie roślinnej czarnohorskich połonin. Najbardziej istotną cechą pasterstwa Czarnohory nieobecną w masywie Kukula, jest utrzymywanie się wypasu owiec i to zarówno w gospodarstwach indywidualnych, jak i komunalnych. Kolejną $\mathrm{z}$ istotnych cech pominiętą w badaniach zespołu J.Gudowskiego, jest organizacja wypasu zwierząt przez gromady terytorialne, zarówno wypasu owiec, jak i bydła, a także zarastanie połonin, które w przypadku czarnohorskich połonin nie ogranicza się wyłącznie do połonin nieużytkowanych pastwiskowo.

Ze względu na podejście badawcze, w którym jako obiekt badań przyjęto połoninę, niektóre z uzyskanych wyników badań przeobrażeń pasterstwa, nie mogą być 
ekstrapolowane na większy obszar (Czarnohorę lub całą Huculszczyznę), tym samym trudno rozważać ich reprezentatywność.

Wybrane przez zespół badawczy połoniny reprezentują jedynie najniżej położone pastwiska śódleśne, objęte wypasem bydła w gospodarstwach rodzinnych. Przy założeniu, że wypas bydła w formie gromadzkiej nie odgrywa w skali całej Huculszczyzny tak dużej roli, jaką odgrywa on w Czarnohorze, wyniki badań prowadzonych na połoninach Kukula mogłyby moim zdaniem być reprezentatywne dla huculskiego wypasu bydła. Trudno to rozstrzygnąć - z powodu enigmatycznego potraktowania zagadnienia ich statusu własnościowego oraz zmian w stosunkach własnościowych w badanym piętnastoleciu, a także z powodu pominięcia roli statusu ochronnego połonin.

\section{Literatura}

Caryk J.W., Małynowskyj K.A., 1997, Monitorynh shasania pastoralnych system pid wptywom zapowidannja, [w:] Ja. I. Mowczan (red.), Bioriznomanittia Karpatskoho biosfernoho zapowid$n y k a$, Interekocentr, Kyjiw, 429-440.

Czetwertyna zbudowanych lisowych dorih obtasti - u Rachiweskomu $Ł D H(13.11 .2016)$, http://zorka. in.ua (30.12.2016).

Gudowski J., 2001a, Organizacja i ekonomika gospodarki pasterskiej na Huculszczyænie. Stan obecny na tle tradycji, [w:] J. Gudowski (red.), Pasterstwo na Huculszczyźnie. Gospodarka, kultura, obyczaj, Wyd. Akad. Dialog, Warszawa, 21-62.

Gudowski J. (red.), 2001b, Pasterstwo na Huculszczyźnie. Gospodarka, kultura, obyczaj, Wyd. Akad. Dialog, Warszawa.

Gudowski J., 2011a, Perspektywy ekonomiczne gospodarki pasterskiej na Huculszczyঞnie w XXI wieku: zanik pasterstwa czy poczqtek rozkwitu biznesu? [w:] J. Gudowski (red.), Przeksztatcenia gospodarki pasterskiej w ukrainskich Karpatach, Wyd. Akad. Dialog, Warszawa, 25-36.

Gudowski J. (red.), 2011b, Przeksztatcenia gospodarki pasterskiej w ukrainskich Karpatach, Wyd. Akad. Dialog, Warszawa.

Gudowski J. (red.), 2016, Pasterstwo w Cæarnohoræe. Przyczynki do badan kultury huculskiej, Fundacja Kultury Duchowej Pogranicza, wyd. I, Lublin.

Gudowski J., Hucuł-Stróżewski J., 2016, Gospodarka na połoninach, [w:] J. Gudowski (red.), Pasterstwo w C:arnohorze. Przyczynki do badań kultury huculskiej, Fundacja Kultury Duchowej Pogranicza, wyd. I, Lublin, 21-29.

Harasymczuk R.W., Tabor W., 1937, Etnografia potonin huculskich, Lud, 35, 76-161.

Hucuł-Stróżewski J., 2011, Żywienie i pielegnacja oraz użytkowość i rasy zwierzqt, [w:] J. Gudowski (red.), Przeksztatcenia gospodarki pasterskiej w ukraińskich Karpatach, Wyd. Akad. Dialog, Warszawa, 37-48.

Informacija pro wykorystannja pasowyszcz (potonyny) stanom 1.07.2015 roku - Dane o umowach na dzierżawy połonin zawartych przez Werchowynską Rejonową Administrację Państwową, Werchowyna, 2015. 
Kłymyszyn O., Korżynskyj Ja., Inkin Je., 2007, Wpływ zapowidannja na widnowlennja klimatycznoji werchnoji meżi lisu w Cisornohori (Ukrajinski Karpaty), Wisnyk Lwiwskoho Uniwersytetu, Ser. Biołohiczna, 45, 115-120.

Krukar W., Troll M. (red.), 2013, Czarnohora. Mapa turystycะno-nazewnicะa, skala 1: 50 000, Wydawnictwo Ruthenus, Krosno.

Kubijowicz W., 1926, Życie pasterskie w Beskidach Wschodnich, Prace Instytutu Geograficznego UJ, 5, ss. 109.

Kubijovyč V., 1935, Pastýřský Život v Podkarpatské Rusi. Díl I - Text, Zemepisné Práce, 8, 94.

Kubijovyč V., 1937, Pastýrský Život v Podkarpatské Rusi. Díl II - Tabulky, Mapy, Vyobrazení, Zemepisné Práce, 10, b.p.

Kucharzyk S., 2006, Ekologiczne znaczenie drzewostanów w strefie górnej granicy lasu w Karpatach Wschodnich i ich wrażliwość na zmiany antropogeniczne, Roczniki Bieszczadzkie, 14, 15-43.

Kuźnicka E., 2008, Turystyka wiejska - gospodarstwa agroturystyczne i ekologiczne w Polsce oraz krajach Unii Europejskiej, [w:] R. Niżnikowski (red.), Hodowla i chów owiec, SGGW, Warszawa, 139-152.

Ławruk M., 2011a, Heohgrafija potonynskoho hospodarstwa Huculszczyny na pocz. XXI st., Wisnyk Lwiwskoho uniwersytetu, Ser. Heohraficzna, 39, 218-231.

Ławruk M., 2011b, Istoryko-heohraficzni ta socjalno-ekonomiczni aspekty rozwytku widhinno-potonynskoho twarynnyctwa Huculszczyny, [w:] O. Maslianyk, P. Siredżuk (red.), Huculszczyna w homoni wikiw. Materiały miżnarodnoji naukowo-praktycznoji konferencji. Lwiw, 6 trawnia 2011 r., Triada pljus, Lwiw, 176-215

Marciszuk Sz., 2016, Młodziez $i$ dzieci na potoninach, [w:] J. Gudowski (red.), Pasterstwo w Ciarnohorze. Przyczynki do badań kultury huculskiej, Fundacja Kultury Duchowej Pogranicza, wyd. I, Lublin, 55-58.

Markowski Z., Janowski B., Swederski W., Pawlikowski J., 1928, Uwagi w sprawie «agospodarowania potonin wschodnio karpackich w Wojewódætwie Stanistawowskiem, Okręgowy Urząd Ziemski we Lwowie, Lwów, maszynopis powielony.

Metera E., Sakowski T., Słoniewski K., Romanowicz B., 2010, Grazing as a tool to maintain biodiversity of grassland - a review, Animal Science Papers and Reports, 28 (4), 315-334.

Męciński Z., 1938, Studia zootechnicæne nad owca górskq na Huculszczyænie, Prace Rolniczo-Leśne PAU, 29.

Molik E., Błasiak M., 2015, Alternatywne kierunki ü̇ytkowania owiec szansq na præetrwanie drobnych gospodarstw na terenach gór i pogórza, Problemy Drobnych Gospodarstw Rolnych, $1,29-41$.

Mroczkowski S., 2004, Pielegnowanie krajobrazu za pomocq owiec, [w:] Z. Mirek, M. Nowak (red.), Miejsce wypasu i gospodarki owczarskiej w koncepcji rozwoju «równoważonego, Instytut Botaniki PAN w Krakowie, 39-43.

Na Werchowynszczyni wziatysia $\approx a$ wiwczarstwo, 2011, http://news.if.ua/news/17904.html (30.12.2016). 
Nesteruk J., 2001, Szata roślinna wschodniokarpackich potonin i ochrona strefy wysokogórskiej, [w:] J. Gudowski (red.), Pasterstwo na Huculszczyঞnie. Gospodarka, kultura, obyczaj, Wyd. Akad. Dialog, Warszawa, 63-78.

Nesteruk J., 2011, Perspektywa środowiskowa, [w:] J. Gudowski (red.), Præeksætatcenia gospodarki pasterskiej w ukrainskich Karpatach, Wyd. Akad. Dialog, Warszawa, 49-60.

Nesteruk J., 2016, Sæata roślinna cæarnohorskich połonin, [w:] J. Gudowski (red.), Pasterstwo w Cisarnohorze. Przyczynki do badań kultury huculskiej, Fundacja Kultury Duchowej Pogranicza, wyd. I, Lublin, 21-29.

Perelik wysokohirnych pasowyszc: (połonyn), sa mezamy naselenych punktiw, nadanych terytorialnym hromadam rajonu dlja wypasu chudoby w litnio-osinniomu periodi 2011 roku-Dane Rachowskiej Rejonowej Administracji Państwowej, Rachów, 2011.

Petriw T., 2008, Potonyny Rachiweszczyny optom ta w rozdrib podityły mi: soboju batohiweski chotyji, http://takje.livejournal.com/39646.html (30.12.2016).

Public:na kadastrowa karta, http://map.land.gov.ua/kadastrova-karta; Kadastrowaja karta, http://gisfile.com/map (30.12.2016).

Shandra O., Weisberg P., Martazinova V., 2013, Influences of climate and land use history on forest and timberline dynamics in the Carpathian Mountains during the twentieth century, [w:] J. Kozak, K. Ostapowicz, A. Bytnerowicz, B. Wyżga (red.), The Carpathians: Integrating Nature and Society towards Sustainability, Environmental Science and Engineering, Springer, BerlinHeidelberg, Germany, 209-223.

Sitko I., Troll M., 2008, Timberline Changes in Relation to Summer Farming in the Western Chornohora (Ukrainian Carpathians), Mountain Research and Development, 28 (3-4), 263-271.

Sobala M., 2014, Krajobrazy pasterskie w Polsce i Europie - wybrane typy, przyktady i formy ich ochrony, Prace Komisji Krajobrazu Kulturowego, 25, 81-98.

Środoń A., 1948, Górna granica lasu na Czarnohorze i w Górach Czywczyńskich, Rozprawy Wydziału Matematyczno-Przyrodniczego AU, 72.

Troll M., 2010, Czarnohorskie staje, [w:] W. Krukar, M. Troll, Czarnohora. Mapa turystyczno-nazerwic $a$, skala 1: 60 000, Wydawnictwo Ruthenus, Krosno.

Troll M., 2012, O zmianach wtasności potonin po pokuckiej stronie Cizornej Hory (Popa Iwana), Płaj, 45, 56-67.

Troll M., 2013, Podziat wtasnościowy potonin pokuckiej czessci Ciarnohory w potowie XIX w., [w:] W. Krukar, M. Troll, (red.), C\&arnohora. Mapa turystyc»no-nazewnic»a, skala 1: 50 000, Wydawnictwo Ruthenus, Krosno.

Troll M., Sitko I., 2006, Pasterstwo w zachodniej C\&arnohorze (Karpaty Ukraińskie) w ujęciu przestrzenno-czasowym, [w:] M. Troll (red.), Czarnohora. Przyroda i człowiek, Instytut Geografii i Gospodarki Przestrzennej UJ, Kraków, 111-140.

Tur-Marciszuk K., 2016, Kobieta na potoninie, [w:] J. Gudowski (red.), Pasterstwo w C:arnohorze. Przyczynki do badań kultury huculskiej, Fundacja Kultury Duchowej Pogranicza, wyd. I, Lublin, 31-53. 
Warchalska-Troll A., Troll M., 2014, Summer Livestock Farming at the Crossroads in the Ukrainian Carpathians: The Unique Case of the Chornohora Mountain Range, Mountain Research and Development, 34 (4), 344-355.

Witkowski W., 2001, Kultura materialna - potoninne budownictwo, [w:] J. Gudowski (red.), Pasterstwo na Huculszczyźnie. Gospodarka, kultura, obyczaj, Wyd. Akad. Dialog, Warszawa, 159-223. Witkowski W., 2011, Kultura materialna - pasterskie budownictwo, [w:] J. Gudowski (red.), Præeksztatcenia gospodarki pasterskiej w ukrainskich Karpatach, Wyd. Akad. Dialog, Warszawa, 75-104.

Witkowski W., 2016, Kultura materialna - osadnictwo i budownictwo na potoninach, [w:] J. Gudowski (red.), Pasterstwo w Cæarnohoræe. Przyczynki do badań kultury huculskiej, Fundacja Kultury Duchowej Pogranicza, wyd. I, Lublin, 63-105.

Woźnowski M., 1930, Jednostki antropogeograficzne potonin cæarnohorskich, [w:] L. Sawicki (red.), Pamiętnik II. Zjazdu Słowiańskich Geografów i Etnografów odbytego w Polsce w roku 1927, 2, Kraków, 64-72.

\author{
Mateus: Troll \\ Uniwersytet Jagiellonski \\ Instytut Geografii i Gospodarki Przestrzennej \\ ul. Gronostajowa 7, 30-387 Kraków \\ mateusz.troll@uj.edu.pl
}

